\title{
The Effect of Sulfurization Process on Flotation of Copper Ore Containing Gold and Silver
}

\author{
Ibrahim TEĞİN and Recep ZIYADANOĞULLARI* \\ Department of Chemistry, Faculty of Science and Art, Dicle University, \\ 21280 Diyarbakir, TURKEY \\ * Fax: +90-412-2488039 Tel : +90-412-2488550/3159 E-mail: recepz@ dicle.edu.tr
}

\begin{abstract}
In this study, experiments were carried out on copper ore containing gold and silver obtained from Kisecik village of Hatay, which is in the south of Turkey. Analyses of original ore showed that the sample contained $4.93 \% \mathrm{Cu}, 0.007 \% \mathrm{Co}, 0.92 \% \mathrm{Zn}, 11.41$ $\% \mathrm{Fe}, 10.72, \% \mathrm{~S}, 4.72 \mathrm{~g} / \mathrm{t} \mathrm{Au}$ and $12.80 \mathrm{~g} / \mathrm{t} \mathrm{Ag}$. It was determined that gold and silver could not be reached with satisfactory yields by flotation of original ore at the defined size. Thus, original ore was sulfurized before the flotation. By the flotation of the sulfurized ore, it was seen that $\mathrm{Au}, \mathrm{Ag}, \mathrm{Cu}, \mathrm{Zn}$ and $\mathrm{Co}$ were collected with fairly high yields in the concentrate phase. In the optimum flotation conditions, all of gold, $96.52 \% \mathrm{Ag}, 98.52 \%$ $\mathrm{Cu}, 97.20 \% \mathrm{Zn}$ and $94.77 \%$ Co passed into concentrate phase. The concentrate grades of $\mathrm{Au}, \mathrm{Ag}, \mathrm{Cu}, \mathrm{Zn}$ and Co were found as $8.62 \mathrm{~g} / \mathrm{t}, 21.42 \mathrm{~g} / \mathrm{t}, 7.81 \%, 0.01 \%$, and $1.81 \%$, respectively. From the concentrate obtained from this process, it was determined that $A u$, $\mathrm{Ag}, \mathrm{Cu}, \mathrm{Zn}$ and $\mathrm{Co}$ can be recovered by hydrometallurgical method.
\end{abstract}

The effect of the parameters such as $\mathrm{pH}$, pulp density, particle size and collector amount were investigated. KAX was used as collector and Dow-250 was used as frother.

Key Words: Sulfurization, flotation, copper, gold, silver

\section{INTRODUCTION}

Flotation has been utilized in the mineral processing industry to concentrate base metals and gold from sulphide ores since the beginning of the century. Many novel applications and fundamental studies have been produced to date to gain a more thorough understanding of the chemical and physical phenomena that occur within the solid-water pulp matrix. However, regardless of all the information that has been acquired during this 
time, the flotation behavior of gold bearing minerals, especially free gold particles and refractory gold bearing sulphides, remains largely unclear. There have been numerous studies on the flotation of free gold particles as far back as 1934 by Leaver and Woolf [1] and more recently by Aksoy and Yarar [2], but these investigations have focused on the flotation behavior of gold in synthetic mixtures and not when it is a component of a real ore containing other gold bearing sulphide minerals and siliceous gangue. There are also some research documented on the flotation of gold bearing pyrites [3] and arsenopyrite [4]. However, these studies have not included free gold particles.

The best processing method for recovering gold is ultimately determined by the mineralogy and particle size distribution of the gold. Gold particles vary in size from large nuggets to particles locked in the crystal lattice of certain sulphide minerals [5]. These gold particles or components occurred typically in a sulphide or quartz matrix. They are usually liberated after milling to between 60 and $80 \%$ smaller than $75 \mu \mathrm{m}$. Grinding ores finer than this is usually uneconomic unless the ore has a very high gold content. Often the gold bearing ores are refractory due to smallness of the gold grains and concentration by flotation is required, followed by roasting, bacterial leaching or pressure leaching to liberate the gold prior to cyanidation $[5,6,7]$.

Studies were carried out on a sample previously investigated by the Mining Technical Research Institute of Turkey. However, it was determined that flotation yields of $\mathrm{Cu}, \mathrm{Au}$ and $\mathrm{Ag}$ were fairly low. Gold and silver or their components in sulphide or quartz matrix did not liberated though it was ground up to -300 meshes (8).

In this study, we aimed to collect gold, silver and copper in same phases and to increase flotation yield. Thus, before the flotation, process of sulfurization was made in order to change the ore structure and surface properties $(9,10$ and 11). The sulfurized samples were subjected to flotation and the results were evaluated.

\section{MATERIALS AND METHOD}

\subsection{Materials}

The copper ore containing gold and silver used in this study was obtained from Kisecik village of Hatay, which is in southern part of Turkey. About $100 \mathrm{~kg}$ of mine sample was taken. Analyses showed that the sample contained $4.93 \% \mathrm{Cu}, 0.067 \% \mathrm{Co}$, $0.92 \%$ Zn 11.41, \% Fe, $10.72 \%$ S, 4.72 g/t Au and 12.80 g/t Ag.

$\mathrm{H}_{2} \mathrm{SO}_{4}(98 \%(\mathrm{w} / \mathrm{v})), \mathrm{HCl}(37 \%(\mathrm{w} / \mathrm{v})), \mathrm{HNO}_{3}(65 \%(\mathrm{w} / \mathrm{v}))$ and $\mathrm{KClO}_{3}$ were purchased from Merck.

The K-Amyl xanthate and Dow-250 used in flotation were provided from the Ergani Copper Mining Co. in Turkey. 
A flame atomic absorption spectrometer (Unicam 929 Model AAS) was used for the determination of $\mathrm{Cu}, \mathrm{Zn}, \mathrm{Co}, \mathrm{Au}$ and $\mathrm{Ag}$ concentrations in the solution. The sulfur analysis was carried out gravimetrically by precipitating it as $\mathrm{BaSO}_{4}$ (12). Denver Mark and 890 Model $\mathrm{pH}$ meter were used for flotation and determination of $\mathrm{pH}$ of samples, respectively.

The sulfurization process was conducted in an autoclave of 1.3 liter internal volume, resistant to $250 \mathrm{~atm}$ pressure and to $350{ }^{\circ} \mathrm{C}$

\subsection{Method}

The mine sample was first crushed and then ground to -160 mesh size, sieved and dried at $110^{\circ} \mathrm{C}$.

For sulfurization, $500 \mathrm{~g}$ of sample was sulfurized with gas containing different amounts $\mathrm{H}_{2} \mathrm{~S}+\mathrm{H}_{2} \mathrm{O}$ in an autoclave for 1 hour at $150{ }^{\circ} \mathrm{C}$ and at $1.5-2$ atmosphere. Then, samples obtained from autoclave were floated by using potassium amyl xanthate and Dow250.

\section{RESULTS AND DISCUSSION}

\subsection{Flotation of Original Ore}

In this study, the effects of parameters such as particle size, $\mathrm{pH}$ of the medium, pulp density, collector amount and activator addition were examined on the original ore systematically.

$\begin{array}{ll}\text { Flotation condition: } & \\ \text { Particle size } & :-160 \mathrm{mesh} \\ \text { Solid / Liquid Rate } & : 100 \mathrm{~g} / \mathrm{L} \\ \text { Collector } & : 0.2 \mathrm{~g} \mathrm{Z} \text { (potassium amyl xanthate), } 3 \text { Minute mix } \\ \text { Frother } & : 0.5 \mathrm{~mL} \text { Dow-250 (1\%), 2 Minute mix } \\ \text { pH } & : 11.00 \\ \text { Mix Speed } & : 900 \mathrm{RPM}\end{array}$

For flotation, $100 \mathrm{~g}$ of the ore sample was fed and $38.02 \mathrm{~g}$ of ore sample was floated. The flotation yields of $\mathrm{Au}, \mathrm{Ag}, \mathrm{Cu}, \mathrm{Zn}$ and $\mathrm{Co}$ were determined as $49.31 \%, 86.80$ $\%, 86.30 \%, 85.74 \%$ and $72.54 \%$, respectively and their concentrate grades of $\mathrm{Au}, \mathrm{Ag}$, $\mathrm{Cu}, \mathrm{Zn}$ and $\mathrm{Co}$ were ascertained as $7.31 \% \mathrm{Au}, 24.30 \% \mathrm{Ag}, 11.35 \% \mathrm{Cu}, 1.69 \% \mathrm{Zn}$ and $0.016 \%$ Co. At the end of flotation process, the results aimed were not attained, and flotation yield was low. Thus, original ore was sulfurized in an autoclave before flotation. Then, these samples were floated. 


\subsection{Flotation of Sulfurized Samples}

\subsubsection{Effect of sulfurization}

Firstly, the copper ore containing gold and silver were ground, sieved to -160 mesh size, dried at $110{ }^{\circ} \mathrm{C}$ and then reacted with gas mixtures containing different amounts of $\mathrm{H}_{2} \mathrm{~S}+\mathrm{H}_{2} \mathrm{O}$ for 1 hour at $150{ }^{\circ} \mathrm{C}$ at $1.5-2$ atmosphere. For this purpose, the six samples each of which was $500 \mathrm{~g}$, were reacted with mixtures of $\mathrm{H}_{2} \mathrm{~S}$ and $\mathrm{H}_{2} \mathrm{O}$ separately as seen in Table 1.

Table 1- The used amount of gas mixtures of $\mathrm{H}_{2} \mathrm{~S}$ and $\mathrm{H}_{2} \mathrm{O}$.
1. $14.65 \mathrm{~g} \mathrm{H}_{2} \mathrm{~S}+100 \mathrm{~mL} \mathrm{H}_{2} \mathrm{O}$
5. $16.27 \mathrm{~g} \mathrm{H}_{2} \mathrm{~S}+100 \mathrm{~mL} \mathrm{H}_{2} \mathrm{O}$
2. $15.10 \mathrm{~g} \mathrm{H}_{2} \mathrm{~S}+100 \mathrm{~mL} \mathrm{H}_{2} \mathrm{O}$
6. $16.72 \mathrm{~g} \mathrm{H}_{2} \mathrm{~S}+100 \mathrm{~mL} \mathrm{H}_{2} \mathrm{O}$
3. $15.78 \mathrm{~g} \mathrm{H}_{2} \mathrm{~S}+100 \mathrm{~mL} \mathrm{H}_{2} \mathrm{O}$
7. $18.86 \mathrm{~g} \mathrm{H}_{2} \mathrm{~S}+100 \mathrm{~mL} \mathrm{H}_{2} \mathrm{O}$
4. $15.92 \mathrm{~g} \mathrm{H}_{2} \mathrm{~S}+100 \mathrm{~mL} \mathrm{H}_{2} \mathrm{O}$

After sulfurization, the samples were floated under conditions stated below.

\section{Flotation condition:}

$\begin{array}{ll}\text { Particle size } & :-160 \mathrm{mesh} \\ \text { Solid / Liquid Rate } & : 100 \mathrm{~g} / \mathrm{L} \\ \text { Collector } & : 0.2 \mathrm{~g} \mathrm{Z} \text { (potassium amyl xanthate), 3 Minute mix } \\ \text { Frother } & : 0,5 \mathrm{~mL} \text { Dow-250 (1\%), 2 Minute mix } \\ \mathrm{pH} & : 7.50-11.50 \\ \text { Mix Speed } & : 900 \mathrm{RPM}\end{array}$
Figure 1.

The sulfurized sample was floated at different $\mathrm{pHs}$ and the results are given in

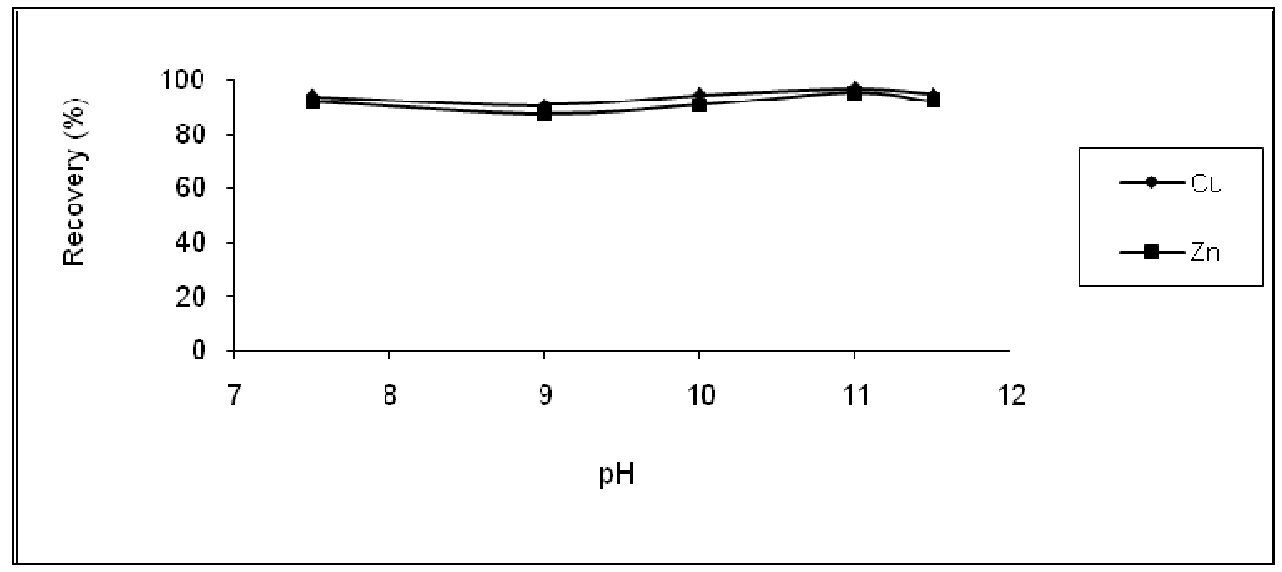

Figure 1: The effect of $\mathrm{pH}$ on the flotation yield

As seen in Figure 1, the best of flotation yield was at $\mathrm{pH}$ 11.0. 
The seven different sulfurized samples were floated under the same conditions. The results are given in Table 2

As seen in Table 2, the best result was obtained from third and fourth sulfurized sample by flotation. In order to understand these results better; they are given in Figure 2 with respect to different $\mathrm{H}_{2} \mathrm{~S}$ values. Then, the studies were carried out on the samples prepared under the condition of third sulfurized sample.

\subsubsection{Effect of the pulp density}

In the next step, flotation process was conducted to test the effect of pulp density. The studies were carried out at pH 11.0 and the weight of sample varied at $200 \mathrm{~g}, 250 \mathrm{~g}$, $300 \mathrm{~g}$ and $350 \mathrm{~g}$. Sulfurization conditions for the third sulfurized sample were utilized and the flotation results are given in Figure 3.

Table 2. The values obtained by flotation of the sulfurized sample

\begin{tabular}{|c|c|c|c|c|c|c|c|c|}
\hline \multicolumn{2}{|c|}{ Sulfurization Number } & 1 & 2 & 3 & 4 & 5 & 6 & 7 \\
\hline \multicolumn{2}{|l|}{$\mathrm{pH}$} & 11.00 & 11.00 & 11.00 & 11.00 & 11.00 & 11.00 & 11.00 \\
\hline \multicolumn{2}{|c|}{ Froth $(\mathrm{g})$} & 31.78 & 44.16 & 51.35 & 50.53 & 41.20 & 49.28 & 43.30 \\
\hline \multicolumn{2}{|c|}{ Tailing (g) } & 68.22 & 55.84 & 48.65 & 49.47 & 58.80 & 50.19 & 56.70 \\
\hline \multirow{5}{*}{ 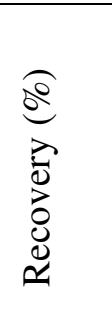 } & $\% \mathrm{Au}$ & 61.85 & 100 & 100 & 99.05 & 100 & 100 & 72,20 \\
\hline & $\% \mathrm{Ag}$ & 77.89 & 89.04 & 97.07 & 98.57 & 70.47 & 83.40 & 71.11 \\
\hline & $\% \mathrm{Cu}$ & 82.46 & 98.56 & 96.62 & 96.27 & 91.01 & 98.6 & 88.03 \\
\hline & $\% \mathrm{Zn}$ & 79.16 & 93.54 & 94.95 & 94.88 & 88.26 & 91.90 & 86.55 \\
\hline & $\% \mathrm{Co}$ & 68.68 & 82.01 & 90.81 & 86.80 & 88.11 & 85.77 & 77.19 \\
\hline \multirow{5}{*}{ 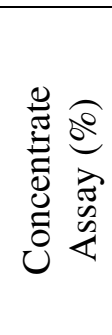 } & $(\mathrm{g} / \mathrm{t}) \mathrm{Au}$ & 9.79 & 8.60 & 8.44 & 9.25 & 9.94 & 8.49 & 7.87 \\
\hline & $(g / t) A g$ & 31.29 & 36.85 & 24.18 & 27.42 & 21.89 & 21.39 & 21.03 \\
\hline & $\% \mathrm{Cu}$ & 12.69 & 10.51 & 9.13 & 10.71 & 9.89 & 9.48 & 9.36 \\
\hline & $\% \mathrm{Zn}$ & 1.62 & 1.80 & 1.99 & 2.18 & 1.95 & 1.54 & 1.79 \\
\hline & $\% \operatorname{Co.} 10^{2}$ & 1.57 & 1.63 & 1.33 & 1.14 & 1.78 & 1.42 & 1.54 \\
\hline \multirow{5}{*}{ 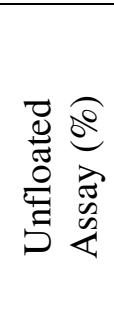 } & $(\mathrm{g} / \mathrm{t}) \mathrm{Au}$ & 2.81 & - & - & 0.05 & - & - & 2.33 \\
\hline & $(g / t) A g$ & 4.14 & 3.59 & 0.62 & 0.41 & 6.53 & 4.33 & 6.54 \\
\hline & $\% \mathrm{Cu}$ & 1.26 & 0.12 & 0.38 & 0.42 & 0.68 & 0.13 & 0.97 \\
\hline & $\% \mathrm{Zn}$ & 0.19 & 0.10 & 0.11 & 0.12 & 0.18 & 013 & 0.18 \\
\hline & $\% \operatorname{Co.} 10^{2}$ & 0.33 & 0.28 & 0.14 & 0.17 & 0.35 & 0.23 & 0.29 \\
\hline \multicolumn{2}{|c|}{ Time (Min) } & 3.15 & 3.50 & 2.53 & 3.46 & 3.00 & 3.32 & 3.46 \\
\hline
\end{tabular}



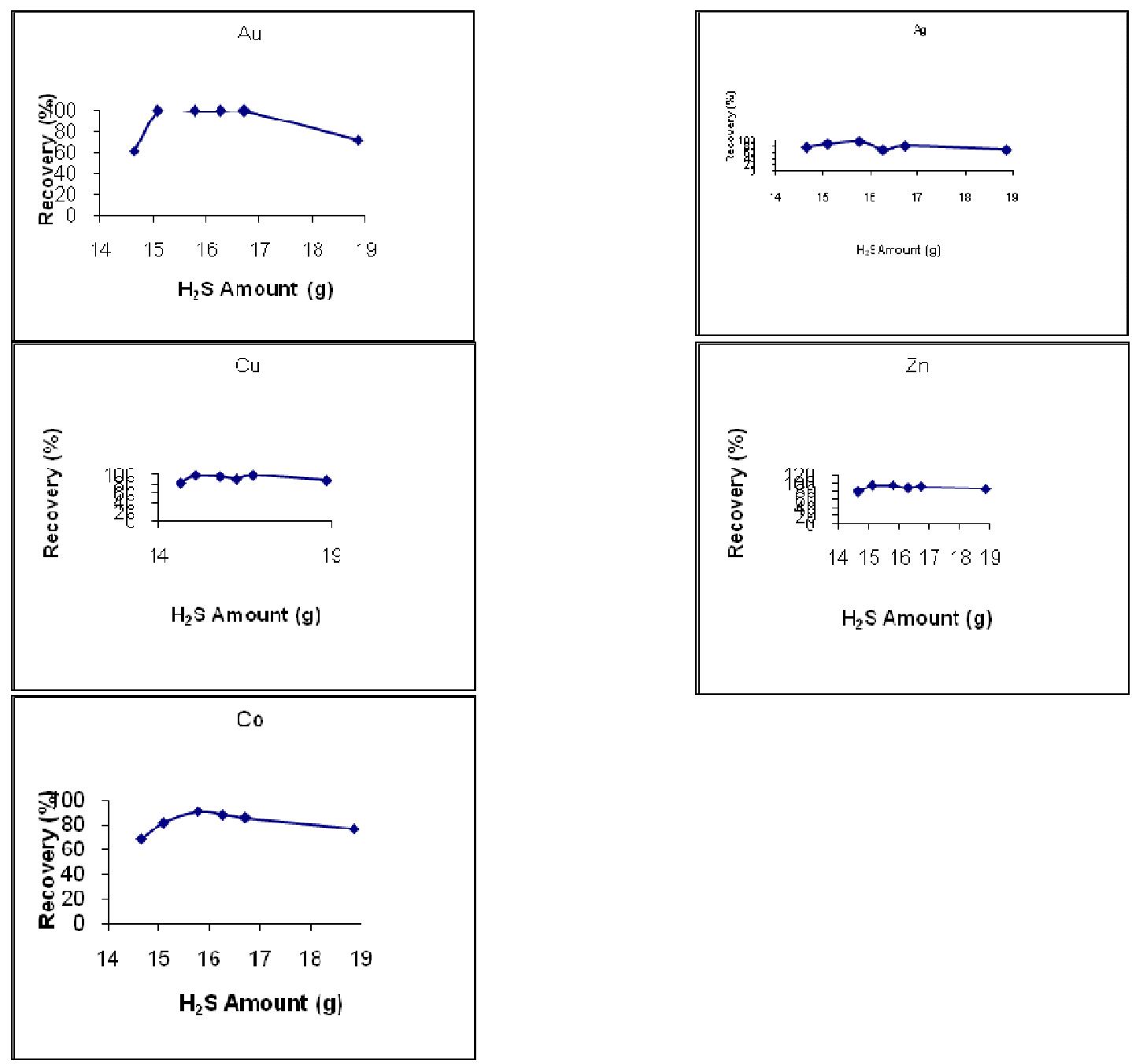

Figure 2. The effect of sulfurization on the flotation yield of sulfurized samples (at pH 11).

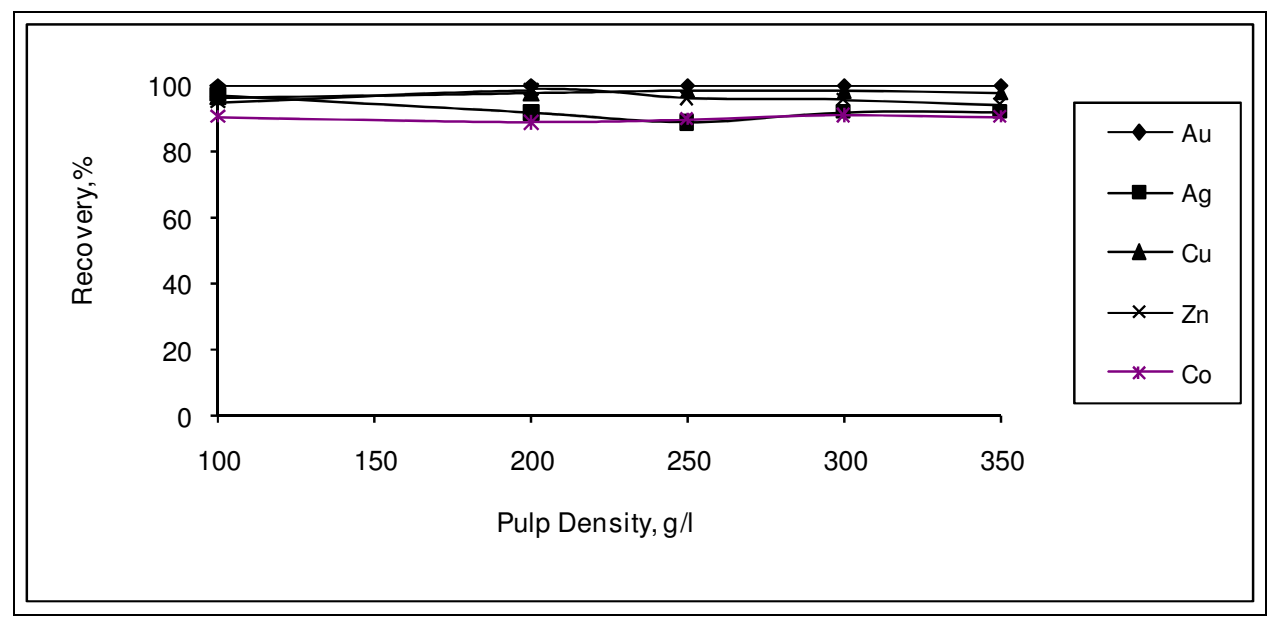

Figure 3. The effect of pulp density on the floatability of the results obtained from third sulfurized sample. 
When Figure 3 is examined, it can be seen that there is no significant difference in flotation yield as pulp density changes. However, the results are better when solid/liquid ratio was done at $35 \%$.

\subsubsection{Effect of the collector amount}

In this step, flotation process on the third sulfurized sample was performed to test the effect of collector amount. The studies were carried out at $\mathrm{pH} 11.0$ and by using $0.20 \mathrm{~g}$, $0.25 \mathrm{~g}, 0.30 \mathrm{~g}$ and $0.35 \mathrm{~g} \mathrm{KAX}$ ( K-amyl xanthate) and the results are given in Figure 4.

When Table 3 and Figure 4 are examined, it can be seen that KAX dosage was optimized at 0.30 g. $96.26 \%$ of Sulfur was passed into concentrate phase and concentrate grade of sulfur was ascertained as $32.32 \% \mathrm{~S}$. For $0.25 \mathrm{~g} \mathrm{KAX}$ dosage, it is determined that $92.88 \%$ of Sulfur was passed into concentrate phase and concentrate grade of sulfur was ascertained as $29.49 \% \mathrm{~S}$. Therefore, it was determined that $0.30 \mathrm{~g} \mathrm{KAX}$ would be sufficient for $350 \mathrm{~g}$ ore. (For 1 ton ore $1,14 \mathrm{~kg} \mathrm{KAX}$ ).

\subsubsection{The effects of the activator and the depressant together}

Flotation studies were conducted by using activator $\mathrm{CuSO}_{4}$ and depressant $\mathrm{Na}_{2} \mathrm{SiO}_{3}$. We found that there was not a significant difference in flotation yield as activator and depressant changes. Thus, the results were not given.

\subsubsection{The $X$-ray spectrum of the original ore and the sulfurized sample}

The X-ray spectrum of the original ore and the sulfurized sample are given in Figure $5 \mathrm{a}$ and $5 \mathrm{~b}$. When the Figure $5 \mathrm{a}$ and $5 \mathrm{~b}$ are examined, the difference of between the original ore and the sulfurized sample is clearly seen.

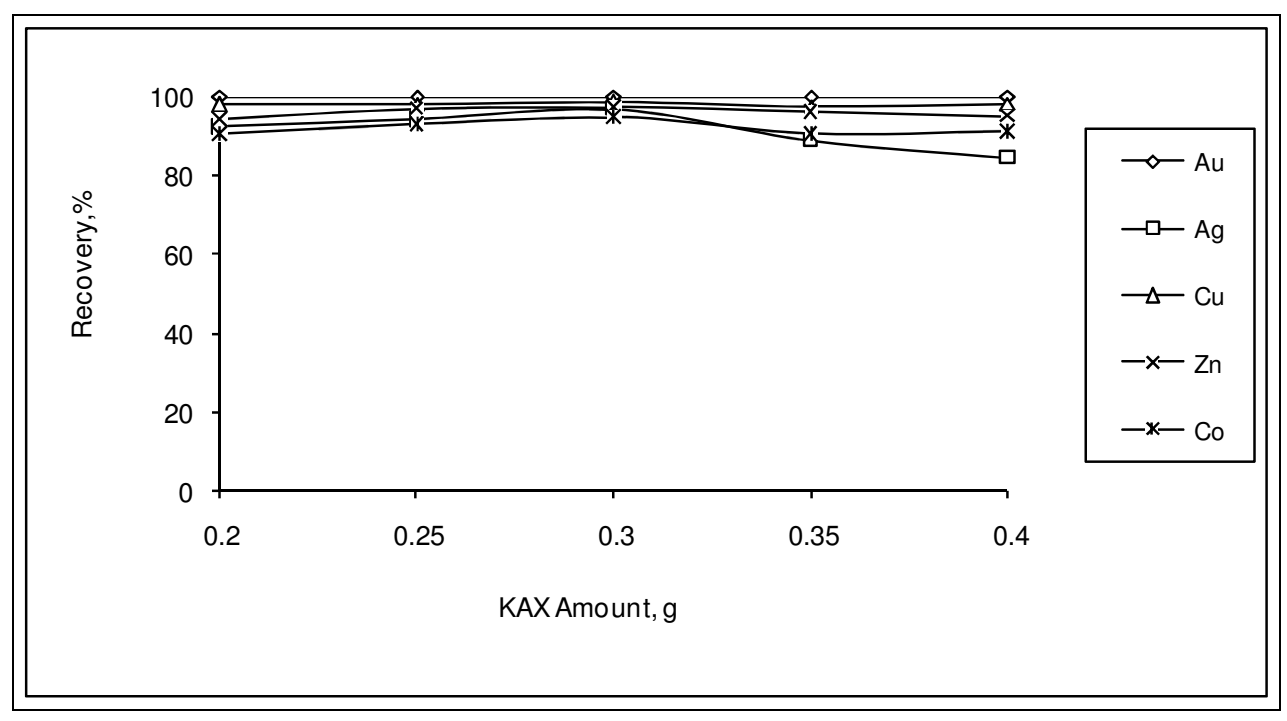

Figure 4. The effect of collector amount on the floatability of the results obtained from third sulfurized sample 
Table 3. The effect of collector dosage on the floatability (Pulp Density: $350 \mathrm{~g} / \mathrm{L}$ ).

\begin{tabular}{|c|c|c|c|c|c|c|}
\hline \multicolumn{2}{|c|}{ KAX Amount (g) } & 0.20 & 0.25 & 0.30 & 0.35 & 0.40 \\
\hline \multicolumn{2}{|l|}{$\mathrm{pH}$} & 11.00 & 11.00 & 11.00 & 11.00 & 11.00 \\
\hline \multicolumn{2}{|c|}{ Froth (g) } & 183.07 & 181.34 & 211.67 & 194.27 & 186.03 \\
\hline \multicolumn{2}{|c|}{ Tailing (g) } & 166.93 & 168.66 & 138.33 & 155.73 & 163.97 \\
\hline \multirow{5}{*}{ 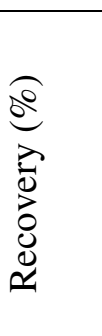 } & $\% \mathrm{Au}$ & 100 & 100 & 100 & 100 & 100 \\
\hline & $\% \mathrm{Ag}$ & 92.27 & 94.22 & 96.82 & 88.79 & 84.36 \\
\hline & $\% \mathrm{Cu}$ & 97.87 & 98.20 & 98.52 & 97.71 & 98.05 \\
\hline & $\% \mathrm{Zn}$ & 94.19 & 96.97 & 97.20 & 96.11 & 95.04 \\
\hline & $\% \mathrm{Co}$ & 90.36 & 92.86 & 94.77 & 90.52 & 90.98 \\
\hline \multirow{5}{*}{ 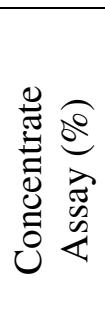 } & $(g / t) A u$ & 7.35 & 8.38 & 8.62 & 7.12 & 7.65 \\
\hline & $(\mathrm{g} / \mathrm{t}) \mathrm{Ag}$ & 22.12 & 21.44 & 20.40 & 20.81 & 19.44 \\
\hline & $\% \mathrm{Cu}$ & 7.24 & 8.00 & 7.81 & 7.68 & 8.27 \\
\hline & $\% \mathrm{Zn}$ & 1.94 & 2.04 & 1.81 & 1.92 & 1.97 \\
\hline & $\% \operatorname{Co.} 10^{2}$ & 1.47 & 1.49 & 1.42 & 1.41 & 1.44 \\
\hline \multirow{5}{*}{ 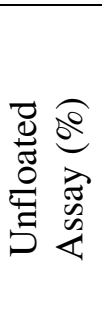 } & $(\mathrm{g} / \mathrm{t}) \mathrm{Au}$ & - & - & - & - & - \\
\hline & $(\mathrm{g} / \mathrm{t}) \mathrm{Ag}$ & 2.22 & 1.08 & 1.08 & 3.24 & 2.78 \\
\hline & $\% \mathrm{Cu}$ & 0.17 & 0.16 & 0.18 & 0.22 & 0.19 \\
\hline & $\% \mathrm{Zn}$ & 0.13 & 0.07 & 0.08 & 0.09 & 0.12 \\
\hline & $\% \operatorname{Co.} 10^{2}$ & 0.17 & 0.12 & 0.12 & 0.18 & 0.16 \\
\hline \multicolumn{2}{|c|}{ Time (Min) } & 2.30 & 2.10 & 3.20 & 2.32 & 2.05 \\
\hline
\end{tabular}




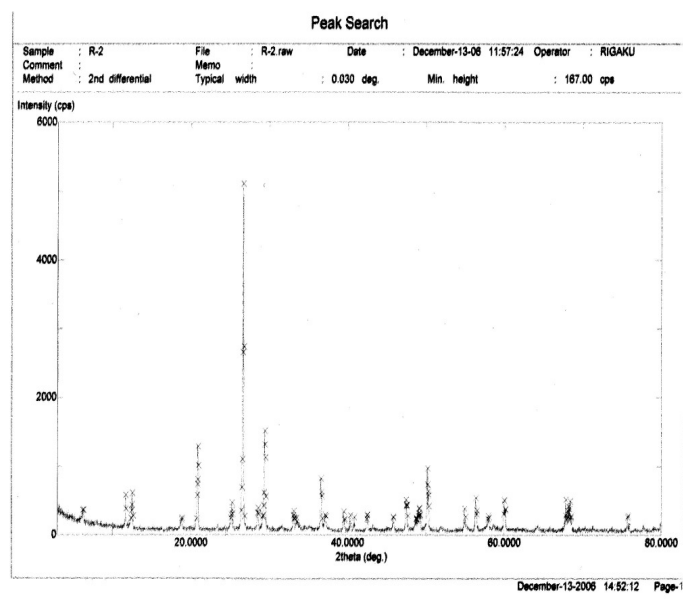

Figure 5a The X-ray spectrum of Original ore

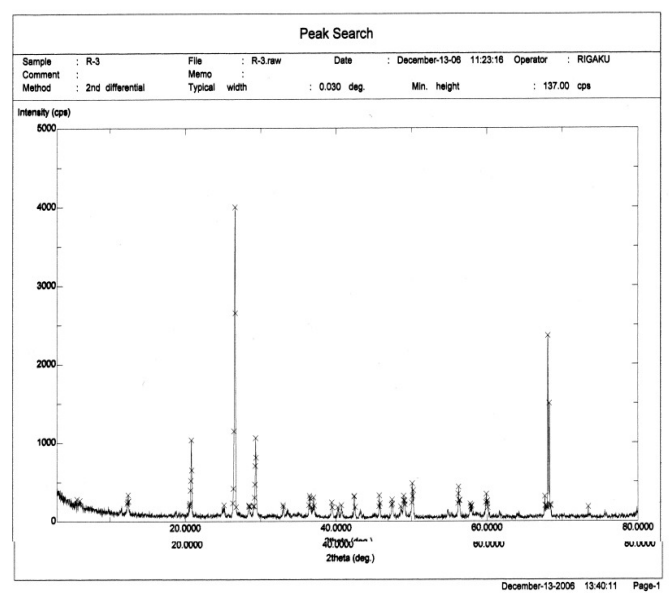

Figure 5b The X-ray spectrum of sulfurized sample under optimum condition

\section{CONCLUSIONS}

The findings for the processing of copper ore containing gold and silver are as follows.

- Collecting gold, silver and copper with high yield from the same phase by direct flotation was not possible, and the flotation yield was low

- Since gold and silver bound to gang minerals, phase separation was not possible (8). Liberation with respect to particle size was unsatisfactory and this resulted low flotation yield.

- In order to achieve an efficient separation by flotation, copper ore containing gold and silver was sulfurized to change its structure and surface. Thus, the sample was sulfurized in a medium containing different amounts of $\mathrm{H}_{2} \mathrm{~S}$ and $\mathrm{H}_{2} \mathrm{O}$ steam. 15,78 $\mathrm{g} \mathrm{H}_{2} \mathrm{~S}+100 \mathrm{~mL} \mathrm{H}_{2} \mathrm{O}$ gas mixture was enough for the sulfurization of $500 \mathrm{~g}$ sieved ore. The sulfurization was finished in 1 hour in the autoclave for at $150{ }^{\circ} \mathrm{C}$

- Under optimal sulfurization conditions, the amounts of $\mathrm{Au}, \mathrm{Ag}, \mathrm{Cu}, \mathrm{Zn}$ and Co in the concentrate obtained from rough flotation were sufficient for hydrometallurgical recovery.

- By developed hydrometallurgical method, it was point out that desired recovery yields could be reached by sulfurization of ore.

- In this study, it was understood that optimum sulfurization condition was also suitable for hydrometallurgical process.

- Since the ore could be recovered after the sulfurization process, selective flotation process was not needed. 


\section{ACKNOWLEDGMENT}

This study was supported by the Research Foundation of Dicle University under project No: DUAPK 02-FF 14

\section{REFERANCES}

1. Leaver, E.S. and Woolf, J.A., Flotation of metallic gold; relation of particle size to floatability. Report of Investigation. U.S. Bureau of Mines, No. 3226, 9-17 (1934).

2. Aksoy, B.S. and Yarar, B., Natural hydrophobicity of native gold flakes and their flotation under different conditions. Processing of Complex Ores. Ed. G.S. Dobby and S.R. Rao. 19-27, Pergamon Press, N.Y., (1989).

3. Botelho De Sousa, A.M.R., O'Connor, C.T. and Dunne, R.C., The influence of various chemical, physical and mineralogical factors on the flotation of goldbearing pyrites. Gold 100. Proc. Int. Conf. on Gold. Vol. 2, Extractive Metallurgy of Gold. 493-503, Johannesburg, S.A.I.M.M., (1986).

4. O'Connor, C.T., Bradshaw, D.J. and Upton, A.E., The use of dithiophosphates and dithiocarbamates for the flotation of arsenopyrite. Minerals Eng., 3(5), 447-459 (1990).

5. Chryssoulis, S.I., Detection and quantification of invisible gold by Microsolse Techniques, Gold 90, (D.M. Housen, ed.), SME Littleton, Colorado, C1-C6 (1990)

6. O'Connor, C.T. and Dunne, R.C., The practice of pyrite flotation in south Africa and Australia, Minerals Eng., 4, (7-11), 1057-1069 (1991).

7. Alison, AS.A., Dunne, R.C. and De Waal, S.A., The flotation of gold and pyrite from South Africa Gold-Mine Residues, Proceedings of $14^{\text {th }}$ international Minerals Processing Congrest, Toronto, Ontario, Canada, II-9.1-II-9.18 (1982).

8. Kumru C, Ulu E., the preprocessing studies of gold ore of Hatay-Kisecik MTA, Turkey

9. Aydın I., Aydın F., Ziyadanoğulları R., Enrichment of U, Mo, V, Ni and Ti from asphaltite ash, Journal of Minerals \& Materials Characterization \& Engineering, Vol. 4, No.1, pp 1-10 (2005)

10. Ziyadanoğulları R., Aydın F., A New Application For Flotation Of Oxidized Copper Ore, Journal of Minerals \& Materials Characterization \& Engineering, Vol. 4, No. 2, pp 67-73 (2005)

11. Akgün A., Teğin İ, Ziyadanoğulları R., Enrichment of Molybdenum and Fluorite by Flotation of Fluorite Ore Containing Molybdenum, Journal of Minerals \& Materials Characterization \& Engineering, Vol. 5, No.2, pp 103-117 (2006)

12. Jeffery, G.H., Bassett, J., Mendham, J. And Deney, R.C., (1975), Vogel's Textbook of Quantitative Chemical Analyses, 5th ed., Longman, London, pp.192-194. 